\title{
Levels and patterns of organochlorine pesticides in agricultural soils in an area of extensive historical cotton cultivation in Henan province, China
}

\author{
Beibei Wang ${ }^{1,2}$ - Chunfa $\mathrm{Wu}^{3} \cdot$ Wuxing Liu ${ }^{1}$ - Ying Teng ${ }^{1}$ Y Yongming Luo ${ }^{1,4}$. \\ Peter Christie $^{1}$ • Dong Guo ${ }^{5}$
}

Received: 20 September 2015 / Accepted: 23 November 2015 /Published online: 9 December 2015

(C) Springer-Verlag Berlin Heidelberg 2015

\begin{abstract}
Organochlorine pesticides (OCPs) have attracted widespread concern because of their environmental persistence and toxicity. The historical influence of different agricultural land use types on soil concentrations of OCP residues was investigated by collecting a total of 52 surface soil samples from long-term cotton fields and fields with other crops in Lvdian township, Henan province, eastern central China. The concentration, composition, and possible sources of 16 OCPs were determined and a health risk assessment of these soils was conducted. Hexachlorocyclohexane $(\mathrm{HCH})$, heptachlor, chlordane, and dichloro diphenyl trichloroethane plus its main metabolites (DDTs) were the most frequently detected OCPs with concentrations of 2.9-56.4 $\mathrm{ng} \mathrm{g}^{-1}, 4.3-14.0 \mathrm{ng} \mathrm{g}^{-1}$, 18.0-1254.4 $\mathrm{ng} \mathrm{g}^{-1}$, and below detection limit (BDL) $-206.1 \mathrm{ng} \mathrm{g}^{-1}$, respectively. Analysis of variance of $\mathrm{p}, \mathrm{p}-$ DDE shows significant $(P<0.05)$ differences while other OCPs show no significant differences between historical cotton fields and fields containing other crops. Compositional analysis suggests that the $\mathrm{HCH}$ is derived mainly from the
\end{abstract}

Responsible editor: Zhihong Xu

Wuxing Liu

liuwuxin@issas.ac.cn

1 Key Laboratory of Soil Environment and Pollution Remediation, Institute of Soil Science, Chinese Academy of Sciences, Nanjing 210008, China

2 University of Chinese Academy of Sciences, Beijing 100049, China

3 Nanjing University of Information Science \& Technology, Nanjing 210044, China

4 Institute of Coastal Zone Research, Chinese Academy of Sciences, Yantai 264003, China

5 Infinitus (China) co., LTD, Jiangmen 529156, Guangdong province, China use of lindane and that there are recent inputs. Analysis of variance and compositional analysis indicate that the p,pDDE in surface soil from long-term cotton fields is derived mainly from the aerobic biodegradation of historical residues. The sum of carcinogenic risk values of OCPs for soil samples were found to be $1.58 \times 10^{-6}$, posing a low cancer risk to the inhabitants of the region studied.

Keywords OCPs $\cdot$ Surface soils $\cdot$ Cotton fields . Compositional analysis $\cdot$ Source identification $\cdot$ Health risk

\section{Introduction}

Soil contamination with organochlorine pesticides (OCPs) such as dichlorodiphenyltrichloroethane (DDT), hexachlorocyclohexane $(\mathrm{HCH})$, chlordane, and heptachlor is of great concern due to their toxicity, bioaccumulation, and persistence in the environment (Yang et al. 2005). the wide distribution of their residues and their carcinogenic properties. They may also affect the normal function of the endocrine and reproductive systems of humans and wildlife (Xue et al. 2005). According to the Stockholm Convention, DDT, hexachlorobenzene (HCB), aldrin, chlordane, dieldrin, endrin, and heptachlor are among the twelve most persistent organic pollutants (POPs). Furthermore, $\mathrm{HCH}$ is considered to be a priority pollutant by the United States Environmental Protection Agency (US EPA) (UNEP 2003).

China is a major agricultural country and is the second largest producer and consumer of pesticides globally (Zhang et al. 2009). From 1952 to 1983 the country produced and consumed more than 4 million tonnes of $\mathrm{HCH}$ insecticides and 0.27 million tonnes of DDT (Zhang et al. 2009). amounting to 46 and $20 \%$ respectively, of global consumption. Although the use of $\mathrm{HCH}$ and DDT was banned in 1983, 
a number of OCPs continue to be used in some areas. According to a report (Li et al. 2001). 3200 tonnes of lindane (at least $99 \% \gamma-\mathrm{HCH}$ ) has been used from 1991 to 2000. Furthermore, DDT continues to be used in China to produce dicofol as an intermediate (Wong et al. 2006).

Even though their production and usage have been officially banned, OCP residues are still found in soils (Shi et al. 2005). waters (Wu et al. 2014). sediments (Yang et al. 2005; Yang et al. 2010). and the air (Qiu et al. 2004). The residue levels have declined substantially but they may still influence environmental quality, human health, and food security (Wang et al. 2007). For example, agricultural soils of the Yellow River Delta (Da et al. 2014). of the Pearl River Delta (Li et al. 2006). and of Jiangsu province (Yang et al. 2008) and Beijing (Shi et al. 2005) have also been reported to contain organochlorine pollution to varying extents. The highest residue levels of DDT (484.24 $\mu \mathrm{g} \mathrm{kg}^{-1}$ ) and $\mathrm{HCH}$ $\left(17.93 \mu \mathrm{g} \mathrm{kg}^{-1}\right)$ have been found in cotton and paddy fields, respectively (Cai 1996). in China. These investigations involve waters, sediments, and agricultural land in general. However, the surveys concentrated in specific land use types are limited and the residue levels and human health risk are unclear after several decades of degradation. In Luoyang, a major cotton-producing area, large amounts of technical $\mathrm{HCH}$ and DDT were used in cotton fields to control cotton bollworms because of a lack of effective biological control measures in the 1970s, and this has resulted in severe historical environmental pollution. However, the current situation of pesticide residues in the region also requires investigation after long periods of metabolism. We therefore targeted our survey of the residue levels of historical cotton fields and fields containing other crops. The objectives of the present study were (1) to determine the concentrations and composition of 16 OCPs in agricultural soils in Lvdian township, an area of extensive historical cotton cultivation in Henan province, (2) to compare the residue levels of the 16 OCPs in two historical land use types, (3) to identify the possible sources of the DDTs and $\mathrm{HCH}$, and (4) to assess the human health risk due to their residues.

\section{Materials and methods}

\section{Study area and sampling}

Lvdian township is located in Luoyang City in the west of Henan province and is characterized by a temperate monsoon climate and four distinct seasons typified by cold and dry winters and hot and rainy summers. The average annual temperature is $14.5^{\circ} \mathrm{C}$ and the mean annual precipitation is approximately $603 \mathrm{~mm}$ with most precipitation occurring from July through September. The township is mainly hilly and mountainous with two major rivers and covers an area of
$124 \mathrm{~km}^{2}$, of which there are 5934 ha of cultivated land area and the township has a population of 5.78 million.

A total of 52 surface $(0-20 \mathrm{~cm}$ depth) soil samples representing 10 field soils historically used to grow crops other than cotton and 42 historical cotton field soils were collected in May 2015. According to an earlier interview survey, representative, and extensive historical cotton cultivation fields in history were sampled as the main research areas, and the sampling points of historical non-cotton fields were sited near to the historical cotton fields. The locations of the samples were relatively evenly distributed across the region (Fig. 1) and the crops in the sampling areas were mainly wheat and rape with a small number of vegetable fields and woodlands and some fallow areas. Samples were collected using a stainless steel shovel. Approximately $500 \mathrm{~g}$ of soil were collected from five points at each sampling site. The samples were stored at $4{ }^{\circ} \mathrm{C}$ for a maximum of seven days before analysis.

\section{Sample extraction and analysis}

The soil samples were freeze-dried and sieved through a 60mesh screen after stones and other debris were removed manually to obtain a homogeneous matrix. The extraction method was adapted from Sui et al. (2013). An aliquot of $1.00 \mathrm{~g}$ soil sample was extracted with $20 \mathrm{~mL}$ of a mixed solution of acetone and hexane $(1: 1 \mathrm{v} / \mathrm{v})$ for $30 \mathrm{~min}$ in an ultrasonic bath followed by centrifugation and then filtered through a filter paper with $5 \mathrm{~g}$ anhydrous sodium sulfate into a concentration bottle. This process was repeated three times to ensure complete extraction. The sample extracts were condensed to near dryness with a rotary evaporator at $300 \mathrm{~Pa}$ and with the water bath temperature maintained at $40{ }^{\circ} \mathrm{C}$. Then $5 \mathrm{~mL}$-hexane was added for solvent exchange and further concentrated to $1 \mathrm{~mL}$. The concentrated solutions were purified by upward passage through a glass column with neutral silica gel $(4 \mathrm{~g})$, acidic silica gel $(0.5 \mathrm{~g})$, and anhydrous sodium sulfate $(1 \mathrm{~g})$ (Zhang et al. 2009) with dichloromethane and n-hexane (4:1). The liquids collected were condensed to $1 \mathrm{~mL}$ and transferred to graduated test tubes. The samples were dried under a gentle stream of nitrogen and pooled together in $1 \mathrm{~mL} \mathrm{n}$-hexane.

The reagents used, n-hexane and dichloromethane were of high performance liquid chromatography (HPLC) grade and the acetone was distilled to remove impurities. Moreover, the anhydrous sodium sulfate and silica were dried at $400{ }^{\circ} \mathrm{C}$ for $6 \mathrm{~h}$ in a muffle furnace before use.

The OCP residues were analyzed by gas chromatography (Agilent 7890B, Santa Clara, CA) equipped with a ${ }^{63} \mathrm{Ni}$ electron capture detector (GC-ECD) and a $30 \mathrm{~m} \times 0.25 \mu \mathrm{m} \times$ $0.25 \mu \mathrm{m}$ HP-5 capillary column. Ultra-high purity $\mathrm{N}_{2}$ $(99.9999 \%)$ was used as the carrier gas. The oven temperature program was as follows: injector and detector temperatures were 200 and $300{ }^{\circ} \mathrm{C}$, respectively, initial run temperature 


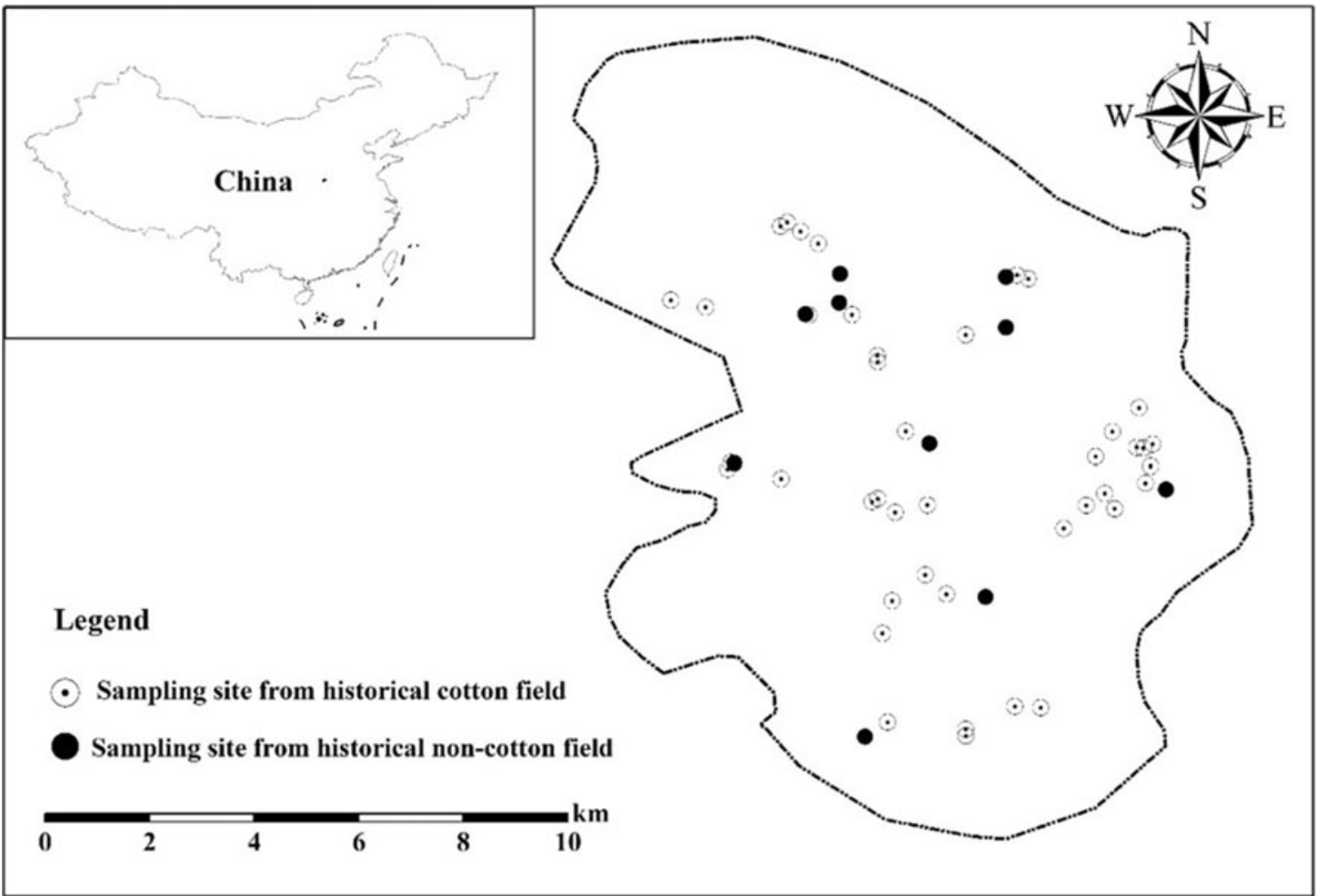

Fig. 1 Map of the study area showing a relatively even distribution of sample sources

was set at $100{ }^{\circ} \mathrm{C}$, ramped at $80{ }^{\circ} \mathrm{C} \min ^{-1}$ to $200{ }^{\circ} \mathrm{C}$, then ramped at $0.5^{\circ} \mathrm{C} \min ^{-1}$ to $206^{\circ} \mathrm{C}$ and held for $1 \mathrm{~min}$, and then ramped at $5{ }^{\circ} \mathrm{C} \min ^{-1}$ to $220^{\circ} \mathrm{C}$ and held for $1 \mathrm{~min}$, and finally ramped at $10^{\circ} \mathrm{C} \mathrm{min}^{-1}$ to $270{ }^{\circ} \mathrm{C}$.

\section{Quality control and quality assurance}

Quantification of OCPs was determined from an external standard comparing peak area. The correlation coefficients $(r)$ of calibration curves of OCPs were all higher than 0.999. A procedural blank sample and a spiked sample with standards were run to check for interference and cross-contamination every 10 samples. The standard solutions were purchased from J\&K Scientific Ltd., Beijing, China. The pesticide recoveries were determined relative to the ratio of direct injection of extract and the working standards $\left(10 \mu \mathrm{g} \mathrm{L}^{-1}\right)$ prepared in $\mathrm{n}$ hexane. Five clean soils were spiked with the standard solution, extracted and analyzed in the same way as the samples. The results are listed in Table 1 . The recovery values ranged from 55 to $110 \%$, of which the recovery of $\alpha-\mathrm{HCH}$ was $55 \%$, lower than those of other $\mathrm{HCH}$ isomers due to its low boiling point and volatility.

\section{Statistical analysis}

Differences in OCP concentrations between historical cotton fields and other fields were compared by analyzing the variances of the two land use types by one-way analysis of variance (ANOVA) using the SPSS 17.0 software package.

\section{Health risk assessment}

Most organochlorine pesticide residues have led to growing concern regarding their potential for contamination of the environment and also associated effects on human health (Shi et al. 2005). Ordinarily, humans may be exposed to OCPs in agricultural soils via ingestion, dermal contact, and inhalation of soil particles. They were estimated based on the following Eqs. (1), (2), and (3), which have been adapted from the U.S. Environmental Protection Agency (USEPA 1997, 2009).

$$
\begin{aligned}
& \text { CRingestion }=\frac{(\mathrm{C} \times \mathrm{IngR} \times \mathrm{EF} \times \mathrm{ED}) \times \mathrm{CF} \times \mathrm{SF}}{\mathrm{BW} \times \mathrm{AT}} \\
& \mathrm{CRdermal}=\frac{(\mathrm{C} \times \mathrm{SA} \times \mathrm{AF} \times \mathrm{ABS} \times \mathrm{EF} \times \mathrm{ED}) \times \mathrm{CF} \times \mathrm{SF}}{\mathrm{BW} \times \mathrm{AT}} \\
& \mathrm{CRinhal}=\frac{(\mathrm{C} \times \mathrm{InhR} \times \mathrm{BF} \times \mathrm{EF} \times \mathrm{ED}) \times \mathrm{IUR}}{\mathrm{PEF} \times \mathrm{AT}}
\end{aligned}
$$

where $\mathrm{C}\left(\mathrm{mg} \mathrm{kg}^{-1}\right)$ is the concentration of OCPs in soil; $\mathrm{CR}_{\text {ingestion }}$ is the cancer risk via accidental ingestion of soil; $\mathrm{CR}_{\text {dermal }}$ is the cancer risk via dermal contact with soil; $\mathrm{CR}_{\text {inhal }}$ is the cancer risk via inhalation of soil; IngR is the ingestion rate, $100 \mathrm{mg} \mathrm{day}^{-1}$ for adults (USEPA 2001). EF is the exposure frequency, 350 days $\mathrm{yr}^{-1}$ (USEPA 1989). ED is the exposure duration, $70 \mathrm{yr}$ for adult and $12 \mathrm{yr}$ for children (USEPA 
Table 1 Recoveries in the analysis of organochlorine pesticides by GC-ECD

\begin{tabular}{llllll}
\hline Compound & Recovery (\%) & RSD (\%) & Compound & Recovery (\%) & RSD (\%) \\
\hline$\alpha-\mathrm{HCH}$ & 55 & 4.21 & o,p-DDT & 90 & 5.78 \\
$\beta-\mathrm{HCH}$ & 67 & 2.36 & p,p-DDT & 89 & 0.75 \\
$\gamma-\mathrm{HCH}$ & 57 & 3.97 & Heptachlor & 66 & 0.15 \\
$\delta$-HCH & 67 & 1.69 & $\gamma$-Chlordane & 95 & 3.05 \\
o,p-DDE & 81 & 1.57 & Endosulfan I & 81 & 3.68 \\
p,p-DDE & 110 & 3.84 & $\alpha$-Chlordane & 72 & 1.24 \\
o,p-DDD & 70 & 6.46 & Dieldrin & 78 & 6.15 \\
p,p-DDD & 71 & 1.26 & Endosulfan sulfate & 80 & 5.60 \\
\hline
\end{tabular}

$R S D$ relative standard deviation

1989). $\mathrm{CF}$ is the conversion factor, $1 \times 10^{-6} \mathrm{~kg} \mathrm{mg}^{-1}$ (USEPA 1997). $\mathrm{SF}$ is the oral slope factor, in this study, $2 \mathrm{~kg}$ day $\mathrm{mg}^{-1}$ (Ge et al. 2013). BW is the average body weight, in this study, $56.8 \mathrm{~kg}$ (MEP 2014). AT is the averaging time, 25,550 days (Ge et al. 2013; USEPA 2001). SA is the exposed skin area, in this study, $5700 \mathrm{~cm}^{2}$ (Qu et al. 2015). AF is the skin adherence factor, $0.2 \mathrm{mg} \mathrm{cm}^{-2} \mathrm{day}^{-1}$ (USEPA 2001). ABS is the dermal absorption factor, for DDT, DDE, and DDD 0.2, for HCH 0.1, for heptachlor 0.2, and for chlordane 0.05 (Health Canada 2004). GIABS is the fraction of contaminant absorbed in the gastrointestinal tract, 1 (Ge et al. 2013; USEPA 1989). InhR is the inhalation rate, $15.8 \mathrm{~m}^{3} \mathrm{~d}^{-1}$ (USEPA 1989). BF is the absorption factor for the lungs, 1 (Ge et al. 2013; USEPA 1989). IUR is the inhalation unit risk, $0.57 \mathrm{mg}^{-1} \mathrm{~m}^{-3}$ (Ge et al. 2013; USEPA 1989). and PEF is the particle emission factor, $1.36 \times 10^{9} \mathrm{~m}^{3} \mathrm{~kg}^{-1}$ (Ge et al. 2013; USEPA 1989).

\section{Results and discussion}

\section{Soil OCP concentrations in the study area}

Concentrations of OCPs detected in the surface soils from historical cotton fields and other fields are shown in Table 2. The total concentration of OCPs ranged from 85 to $1392 \mathrm{ng} \mathrm{g}^{-1}$ with an average value of $213 \mathrm{ng} \mathrm{g}^{-1}$ in historical cotton fields and the corresponding values for other fields were 101 to $394 \mathrm{ng} \mathrm{g}^{-1}$ with a mean value of $173 \mathrm{ng} \mathrm{g}^{-1}$. $\mathrm{HCH}$, heptachlor, and g-chlordane were detected in all of the soil samples with detection rate up to $100 \%$. DDTs were detected in all the historical cotton fields and in all but one of the other fields. The concentration of $\mathrm{HCH}$ ranged from 6.5 to $56.4 \mathrm{ng} \mathrm{g}^{-1}$, with a mean value of $19.0 \mathrm{ng} \mathrm{g}^{-1}$ in historical cotton fields, and ranged from 2.9 to $53.2 \mathrm{ng} \mathrm{g}^{-1}$ with a mean of $21.6 \mathrm{ng} \mathrm{g}^{-1}$ in other fields. The mean residue level of heptachlor was $9.6 \mathrm{ng} \mathrm{g}^{-1}$ in historical cotton fields and $10.3 \mathrm{ng} \mathrm{g}^{-1}$ in other fields. The largest residues of $\mathrm{g}$ chlordane were found in historical cotton fields with concentration up to $1254 \mathrm{ng} \mathrm{g}^{-1}$, higher than the levels of other types of organochlorine pesticide but the average $\left(110 \mathrm{ng} \mathrm{g}^{-1}\right)$ was close to that $\left(99.7 \mathrm{ng} \mathrm{g}^{-1}\right)$ of other fields. The average concentration of DDTs $\left(71.3 \mathrm{ng} \mathrm{g}^{-1}\right)$ in historical cotton fields was higher than that $\left(38.5 \mathrm{ng} \mathrm{g}^{-1}\right)$ in other fields, while the average content of p,p-DDE was $50.3 \mathrm{ng} \mathrm{g}^{-1}$ in historical cotton fields and $18.9 \mathrm{ng} \mathrm{g}^{-1}$ in other fields.

Technical DDT and HCH were produced and consumed widely in China and they have therefore been generally considered to be representative of the composition of OCPs in assessing pollution levels (Zhao et al. 2009). Some survey results of agricultural soils in other regions are listed in Table 3 for comparison with the present study. The soil concentrations of DDTs in our study are somewhat higher than those reported in soils in Fujian but lower than those in soils of Beijing, the northwest and cotton soils of Jiangsu province in east China. According to the Environmental Quality Standard for soils (GB15618-1995), the second grade value for DDTs and $\mathrm{HCHs}$ is proposed to be $<500 \mathrm{ng} \mathrm{g}^{-1}$ for arable land and the first grade tolerance concentration of both DDTs and $\mathrm{HCH}$ is $<50 \mathrm{ng} \mathrm{g}^{-1}$. The GB15618-1995 standard may need to be reviewed in the long-term. If we compare the concentrations of DDTs and HCH in our study with soil environmental quality standard for agricultural land (draft for comment), about $23 \%$ of soil samples in our area exceed the standard value for DDTs and the content of $\mathrm{HCH}$ is below standard value. Other organochlorine pesticides have no clear standards for arable land. Consequently, the soils in this area can be considered to be slightly polluted by OCPs.

\section{Comparison of OCPs residues in different historical land use types}

The mean concentrations of OCPs in historical cotton fields and other fields were compared by one-way analysis of variance. According to the results listed in Table 4, p,p-DDE showed a difference at the $5 \%$ level of significance. The DDTs almost reached significance at the $5 \%$ level with a probability of 0.069 but other components showed no significance differences.

Generally, p,p-DDT is the active ingredient in DDTs and is degraded to $\mathrm{p}, \mathrm{p}$-DDE under aerobic conditions and to $\mathrm{p}, \mathrm{p}$ - 
Table 2 Concentrations $\left(\mathrm{ng} \mathrm{g}^{-1}\right)$ of individual organochloride pesticides in surface soils from historical cotton fields and other fields

\begin{tabular}{|c|c|c|c|c|c|c|}
\hline \multirow[t]{2}{*}{ Compound } & \multicolumn{2}{|l|}{ Range } & \multicolumn{2}{|l|}{ Mean } & \multicolumn{2}{|c|}{ Detection rate $(\%)$} \\
\hline & $\begin{array}{l}\text { Historical cotton } \\
\text { fields }\end{array}$ & $\begin{array}{l}\text { Historical non- } \\
\text { cotton fields }\end{array}$ & $\begin{array}{l}\text { Historical } \\
\text { cotton fields }\end{array}$ & $\begin{array}{l}\text { Historical non- } \\
\text { cotton fields }\end{array}$ & $\begin{array}{l}\text { Historical } \\
\text { cotton fields }\end{array}$ & $\begin{array}{l}\text { Historical non- } \\
\text { cotton fields }\end{array}$ \\
\hline$\alpha-\mathrm{HCH}$ & BDL-12.8 & BDL-3.4 & 1.7 & 0.7 & 40.5 & 20.0 \\
\hline$\beta-\mathrm{HCH}$ & BDL-3.9 & BDL-2.2 & 0.3 & 0.4 & 21.4 & 30.0 \\
\hline$\gamma-\mathrm{HCH}$ & $2.7-19.5$ & $2.9-15.0$ & 7.0 & 7.3 & 100.0 & 100.0 \\
\hline$\delta-\mathrm{HCH}$ & BDL-28.0 & BDL -45.0 & 10.0 & 13.2 & 95.2 & 90.0 \\
\hline $\mathrm{HCH}$ & $6.5-56.4$ & $2.9-53.2$ & 19.0 & 21.6 & 100.0 & 100.0 \\
\hline $\mathrm{o}, \mathrm{p}-\mathrm{DDE}$ & BDL-5.8 & BDL-3.4 & 0.7 & 1.0 & 23.8 & 30.0 \\
\hline p,p-DDE & $8.4-176.7$ & BDL -46.0 & 50.3 & 18.9 & 100.0 & 90.0 \\
\hline o,p-DDD & BDL-2.2 & $\mathrm{BDL}$ & 0.1 & 0 & 2.4 & 0 \\
\hline $\mathrm{p}, \mathrm{p}-\mathrm{DDD}$ & BDL-10.5 & BDL-3.6 & 0.5 & 0.4 & 7.1 & 10.0 \\
\hline o,p-DDT & BDL-25.4 & BDL-6.9 & 4.3 & 3.4 & 59.5 & 60.0 \\
\hline $\mathrm{p}, \mathrm{p}-\mathrm{DDT}$ & $6.3-43.6$ & BDL-59.5 & 15.3 & 14.8 & 100.0 & 90.0 \\
\hline DDTs & $20.0-206.1$ & BDL-79.2 & 71.3 & 38.5 & 100.0 & 90.0 \\
\hline Heptachlor & $4.3-14.0$ & $6.5-13.5$ & 9.6 & 10.3 & 100.0 & 100.0 \\
\hline g-Chlordane & $18.0-1254.4$ & $48.5-317.8$ & 109.9 & 99.7 & 100.0 & 100.0 \\
\hline Endosulfan I & BDL-3.3 & BDL & 0.4 & 0 & 14.3 & 0 \\
\hline a-Chlordane & BDL & $\mathrm{BDL}$ & 0 & 0 & 0 & 0 \\
\hline Dieldrin & $\mathrm{BDL}$ & BDL & 0 & 0 & 0 & 0 \\
\hline Endosulfan sulfate & BDL & BDL & 0 & 0 & 0 & 0 \\
\hline OCPs & $85.0-1392.1$ & $101.3-393.8$ & 212.7 & 173.3 & 100.0 & 100.0 \\
\hline
\end{tabular}

$B D L$ below detection limit; $H C H$ sum of $\alpha-, \beta-, \gamma-$, and $\delta$-HCH isomers; $D D T s$ sum of DDT plus its main metabolites o,p-, p,p-DDE and o,p-, p,p-DDD; $O C P$, sum of 16 organochloride pesticides

DDD under anaerobic conditions (Zhao et al. 2009). Over recent decades the majority of DDT in soils has degraded to DDE and DDD, resulting in the differences between historical cotton fields and other fields. Moreover, the residual quantity of DDE was greater than that of DDT in historical cotton fields (Table 2) and this confirms that the DDT was metabolized to DDE. The residues of DDE in historical cotton fields appear to be larger than those in non-cotton fields. In the environment, $\alpha$ - and $\gamma-\mathrm{HCH}$ can be converted to $\beta-\mathrm{HCH}$, which is more stable than the other $\mathrm{HCH}$ isomers (Kim et al. 2007). However, photochemical transformation and biodegradation may transform $\gamma-\mathrm{HCH}$ to $\alpha-\mathrm{HCH}$ (Strandberg et al. 1998). DDTs are more persistent than $\mathrm{HCH}$ in soil and the residues of $\mathrm{HCH}$ were lower than DDTs in surface soil (2.93 to $56.41 \mathrm{ng} \mathrm{g}^{-1}$ for $\mathrm{HCH}$, and from BDL to $206.13 \mathrm{ng} \mathrm{g}^{-1}$ for DDTs). In addition, the content of $\mathrm{HCH}$ in soil dramatically decreased and showed no significance differences (Table 4) between historical cotton fields and other fields due to the effects of degradation over the long periods. Moreover, the OCPs such as heptachlor and chlordane were widely used in croplands to protect the crops from insect pests. In addition, local farmers cultivated many cotton crops at the tops of hills to obtain increased economics from a large-scale textile mill. As would be expected, the level terrain and areas of slight depression were relatively fertile land and were used to grow food crops. The similar content of other OCPs in historical
Table 3 Comparison of DDT and $\mathrm{HCH}$ levels $\left(\mathrm{ng} \mathrm{g}^{-1}\right)$ in the agricultural soils with the levels reported in other regions

\begin{tabular}{|c|c|c|c|c|c|c|}
\hline \multirow[t]{2}{*}{ Area } & \multirow[t]{2}{*}{ Land use types } & \multicolumn{2}{|l|}{ DDTs } & \multicolumn{2}{|l|}{$\mathrm{HCH}$} & \multirow[t]{2}{*}{ Reference } \\
\hline & & Range & Mean & Range & Mean & \\
\hline Beijing & Agricultural & $7.2-2910.0$ & 381.3 & $2.0-760.3$ & 32.0 & (Shi et al. 2005) \\
\hline Northwestern & Agricultural & $67.1-79.4$ & 74.4 & $86.1-93.9$ & 91.1 & (Wang et al. 2006) \\
\hline Jiangsu & Agricultural & $4.2-678.6$ & 190.4 & $-^{\mathrm{a}}$ & - & (Yang et al. 2008) \\
\hline Fujian & Agricultural & $0.6-78.1$ & 3.9 & $0.7-30.2$ & 9.8 & (Yang et al. 2012) \\
\hline This study & Agricultural & $0-206.1$ & 65.0 & $2.9-56.4$ & 19.5 & \\
\hline
\end{tabular}

${ }^{a}$ no given value 
Table 4 Analysis of variance of individual organochloride pesticides comparing historical cotton fields and fields with other cropping histories

\begin{tabular}{llll}
\hline Component & Significance & Component & Significance \\
\hline$\alpha$-HCH & 0.226 & p,p-DDT & 0.886 \\
$\beta-\mathrm{HCH}$ & 0.822 & DDTs & 0.069 \\
$\gamma-\mathrm{HCH}$ & 0.832 & Heptachlor & 0.505 \\
$\delta$-HCH & 0.177 & $\gamma$-Chlordane & 0.885 \\
$\mathrm{HCH}$ & 0.440 & Endosulfan I & 0.214 \\
o,p-DDE & 0.632 & $\alpha$-Chlordane & $-^{\mathrm{a}}$ \\
p,p-DDE & $0.049_{*}$ & Dieldrin & - \\
o,p-DDD & 0.63 & Endosulfan sulfate & - \\
p,p-DDD & 0.817 & OCPs & 0.594 \\
o,p-DDT & 0.631 & - & - \\
\hline
\end{tabular}

${ }_{*} p<0.05$

${ }^{a}$ no given value;

cotton fields and other fields may be attributable to the wide use of OCPs historically and perhaps also to transfer due to rainfall.

\section{Composition and source identification}

Generally, technical $\mathrm{HCH}$ consists mainly of 55-80\% $\alpha$ $\mathrm{HCH}, 5-14 \% \beta-\mathrm{HCH}, 8-15 \% \gamma-\mathrm{HCH}$, and $2-10 \% \delta-$ $\mathrm{HCH}$ and lindane mostly comprises $>99 \% \gamma-\mathrm{HCH}(\mathrm{Ge}$ et al. 2013). If there were no fresh inputs of technical $\mathrm{HCH}$, $\beta-\mathrm{HCH}$ was usually the predominant isomer in soils owing to its resistance to hydrolysis and environmental degradation as well as the transformation of $\alpha-\mathrm{HCH}$ and $\gamma-\mathrm{HCH}$. As can be seen in Fig. 2, the proportion of $\mathrm{HCH}$ isomers followed the order $\delta-\mathrm{HCH}>\gamma-\mathrm{HCH}>\alpha-\mathrm{HCH}>\beta-\mathrm{HCH}$ and their corresponding contributions were approximately 53, 36, 10, and $1 \%$, respectively. The percentages of $\alpha-\mathrm{HCH}$ and $\beta-\mathrm{HCH}$ decreased compared with the primitive components but the

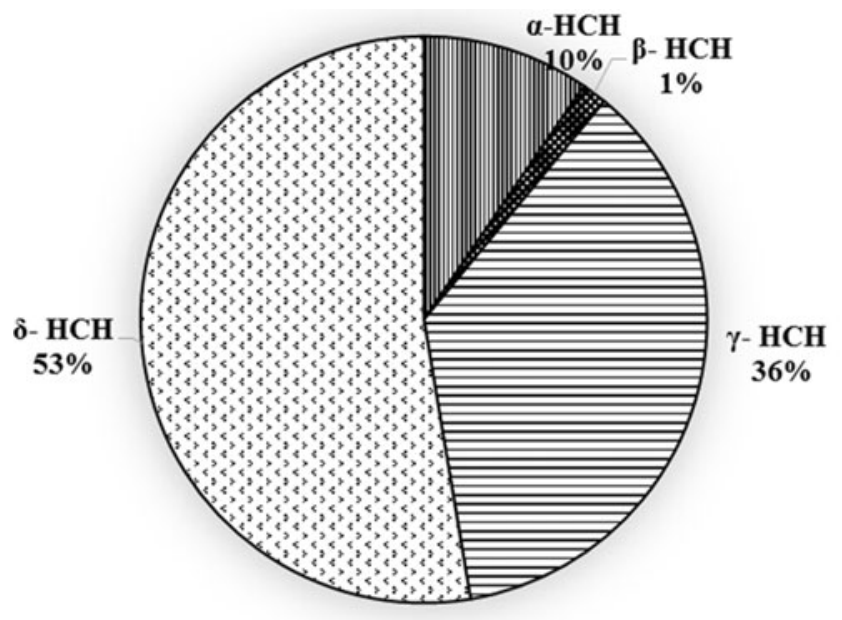

Fig. 2 Average composition of HCHs and DDTs in the surface soils percentages of $\delta-\mathrm{HCH}$ and $\gamma-\mathrm{HCH}$ increased. Generally, $\alpha$-, $\beta$ - and $\gamma-\mathrm{HCH}$ are the most common isomers of $\mathrm{HCH}$ in the environment but much higher concentrations of $\delta-\mathrm{HCH}$ were detected in our present study, similar to the results obtained from the Beijing Guanting reservoir (Xue et al. 2006) and surface sediments of Taihu Lake (Zhao et al. 2009). However, the explanations require further study. Technical $\mathrm{HCH}$ usually posses a $\alpha-\mathrm{HCH} / \gamma-\mathrm{HCH}$ ratio of $4-7$ and a $\beta-/(\alpha+\gamma)-\mathrm{HCH}$ ratio of $0.06-0.17$. For lindane, the $\alpha-$ $\mathrm{HCH} / \gamma-\mathrm{HCH}$ ratio is nearly zero and the $\beta-/(\alpha+\gamma)-\mathrm{HCH}$ ratio is less than 0.06 . Therefore, the values of $\alpha-\gamma-\mathrm{HCH}$ in soil samples can be used to identify the sources of HCHs. As shown in Fig. 3, the ratio of $\alpha-\mathrm{HCH} / \gamma-\mathrm{HCH}$ lay between 0 and 3.30 with a mean value of 0.41 in this study area, much lower than that of technical $\mathrm{HCH}$. This indicates that the source of $\mathrm{HCH}$ might be the use of lindane (Yang et al. $2010)$. The $\beta-/(\alpha+\gamma)-\mathrm{HCH}$ ratio can be used to identify the history of $\mathrm{HCH}$ use, and 0.5 has been used as a threshold (Liu et al. 2012). According to the analysis in the present study, the $\beta-/(\alpha+\gamma)-\mathrm{HCH}$ ratios of the all soil samples were 0.5 , suggesting some recent use of lindane or the existence of an atmospheric source for the input (Liu et al. 2012).

As shown in Figs. 2 and 3, $\delta-\mathrm{HCH}$ and $\gamma-\mathrm{HCH}$ are the main residues of $\mathrm{HCH}$ in all soil samples, and the residue contents in the most samples of historical cotton fields are larger than that in historical non-cotton fields although the analysis of variance showed no significant differences (Table 4). The $\alpha-\mathrm{HCH} / \gamma-\mathrm{HCH}$ ratio was $<4$ for all samples, while the value of $80 \%$ of non-cotton field points is 0 , which indicating that the $\mathrm{HCH}$ in non-cotton fields was mostly derived from lindane. The $\alpha-\gamma-\gamma-\mathrm{HCH}$ for the majority of historical cotton fields was $>0$, implying that the source of $\mathrm{HCH}$ was the application of technical $\mathrm{HCH}$ and lindane. This phenomenon may result from the wide application of technical $\mathrm{HCH}$ in cotton fields for prevention of insect infestation. After several decades of degradation, the residues of $\mathrm{HCH}$ in cotton fields

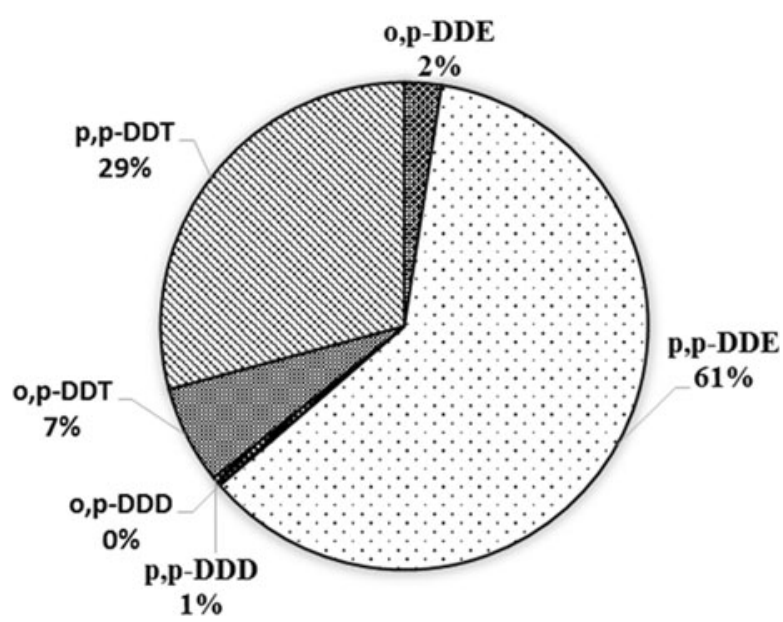


Fig. 3 Relationship between $\alpha$ $\mathrm{HCH}$ and $\gamma-\mathrm{HCH}$ in the surface soils tested

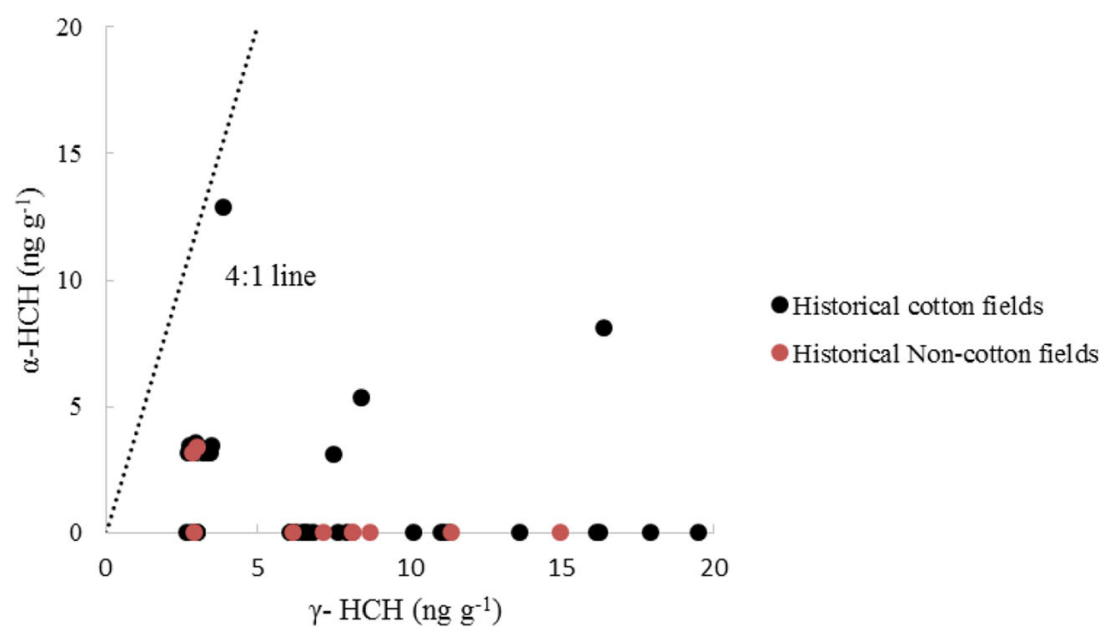

were still detectable and showed a high content versus historical non-cotton fields.

Although the use of technical DDT in China was officially banned in 1983, about 4000-6000 tonnes of DDT continued to be produced annually for export and for use as an intermediate in the production of dicofol (Wei et al. 2007). There remain currently two DDT technical production enterprises and one DDT processing enterprise together with three to five factories producing dicofol in China (NIP 2007). DDT is usually degraded to the stable and toxic metabolites DDE and DDD in soils. As shown in Fig. 2, p,p-DDE was the predominant residue and this may reflect the degradation of DDT under aerobic conditions in the surface soils over a period of several years. It is also noteworthy that $\alpha$-chloro-DDT, one of the components of dicofol, can also be degraded to p, p-DDE (Brown et al. 1986). The sources of the DDTs may be evaluated by analyzing their components in the study area. Technical DDT consists of p,p-DDT (85\%) and o,p-DDT $(15 \%)$ while dicofol often contains impurities in the form of DDTs. The ratios of o,p-DDT / p,p-DDT ranged from 0.2 to 0.3 in technical DDT and ranged from 1.3 to 9.3 in dicofol (Qiu et al. 2005; Yang et al. 2010). Therefore, a o,p-DDT / p,pDDT ratio of $<0.2$ indicates that technical DDT was the main source while a high ratio is thought to indicate pollution by dicofol (Qiu et al. 2005). The o,p-DDT/p,p-DDT ratios found are shown in Fig. 4 and range from 0 to 2.7 with an average value of 0.28 . All the ratios were 1.3 except for one sample, suggesting that the detectable DDTs were derived from both technical DDT and dicofol. A (DDE+DDD)/DDTs ratio of $>0.5$ can be judged to indicate aged DDTs and a ratio much lower than 0.5 can be considered to show recently input DDT (Li et al. 2006). According to Fig. 5, the values in most samples were 0.5 , indicating that long-term weathering of DDTs was the primary source and a minority of samples contained newly input DDTs. DDT can be degraded to DDE under aerobic conditions and to DDD under anaerobic conditions. Hence, the p,p-DDD/p,p-DDE ratio can reflect the biodegradation conditions of $\mathrm{p}, \mathrm{p}-\mathrm{DDT}$ in the region. A p,p-DDD/p,pDDE ratio of $<1$ implies the predominant occurrence of aerobic degradation (Wu et al. 2013). In the present study the p,p$\mathrm{DDD} / \mathrm{p}, \mathrm{p}$-DDE ratio ranged from 0 to 0.94 with a mean of 0.03 , suggesting that the parent DDTs decomposed mainly under aerobic conditions and this is consistent with the plowing method used locally.

According to Fig. 2, the predominant metabolites, DDE and DDD, accounted for $70 \%$ in DDT residues. Moreover, analysis of variance of $\mathrm{p}, \mathrm{p}$-DDE shows significant $(P<$ $0.05)$ differences between the two land use types (Table 4). In addition, as can be seen in Figs. 4 and 5, the content of DDT and DDE+DDD in the majority of samples from historical cotton fields was larger than that in noncotton fields except for one sample. However, the o,p$\mathrm{DDT} / \mathrm{p}, \mathrm{p}-\mathrm{DDT}$ ratio in most samples ranged from 0.2 to 1.3 , suggesting that the source of DDTs was technical DDT combined with dicofol and was undergoing longterm weathering. This could be attributed to vast usage of technical DDT in cotton fields and degradation in the soil. DDE and DDD, the main metabolites of DDT, accumulate in the environment, leading to DDD and DDE becoming the main components of DDTs in the study region.

Heptachlors were produced and used in China in the 1960s and 1970s as a pesticide primarily used against soil insects and termites (Wu et al. 2014) as well as termite control in railway sleepers, and production was halted in 1978. In the present study, the content of heptachlor ranged from 4.30 to $13.95 \mathrm{ng} \mathrm{g}^{-1}$ with a mean value of $9.64 \mathrm{ng} \mathrm{g}^{-1}$ in historical cotton fields and $6.49-13.5 \mathrm{ng} \mathrm{g}^{-1}$ with an average of $10.3 \mathrm{ng} \mathrm{g}^{-1}$ in other fields. In all soil samples tested, the concentrations of heptachlor were much higher than that of heptachlor epoxide (below detection limit, BDL), indicating that 
Fig. 4 Concentration of o,pDDT versus the concentration of p,p-DDT in surface soils from Lvdian township

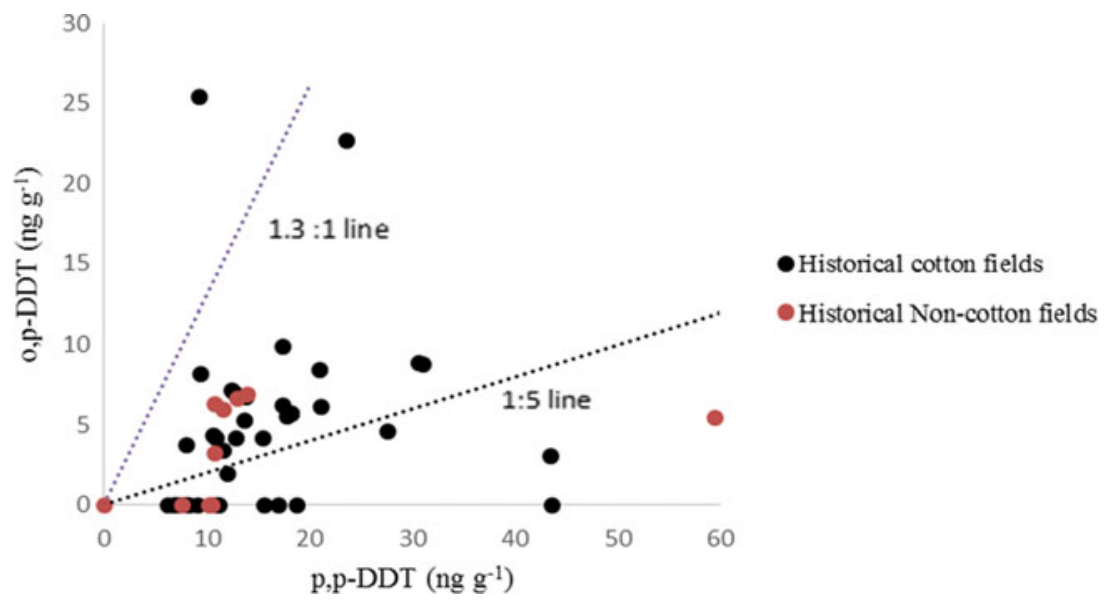

recent applications of heptachlor might be the primary source of fresh inputs of heptachlor.

Chlordane was also widely used against infestation by insects (Boonyatumanond et al. 2002) such as mole crickets, cutworms and white ants. Chlordane was produced at a rate of 9000 tonnes per annum since the $1950 \mathrm{~s}$, and it is still produced and applied. In general, it is a mixture of $\gamma$-chlordane, $\alpha$-chlordane, and heptachlor and the ratio of $\alpha$-chlordane $/ \gamma$-chlordane is about 0.77 (Zhang et al. 2006). An $\alpha$-chlordane $/ \gamma$-chlordane ratio 1.0 suggests that the chlordane is derived mainly from legacy use (Zhao et al. 2013). The ratio in all of our samples was far below 1.0, implying that the chlordane was derived primarily from new inputs in the survey area.

Endosulfan is one of the few organochlorine insecticides that are still in use globally (Qiu et al. 2004). Technical endosulfan typically contains $70 \%$ endosulfan I and $30 \%$ endosulfan II, and endosulfan sulfate is the dominant component in the environment as a result of the photolysis and biodegradation of endosulfan. The detection rate of endosulfan $I$ in our study area was very low at
$14.3 \%$ with none detected in historical cotton fields or other fields and no endosulfan sulfate was detected in the surface soils. Dieldrin (which was not produced or used in China) was not detected in this region.

In summary, source analysis indicates that the OCP residues are derived not only from historical use but also occur in new inputs, especially heptachlor and chlordane. $\mathrm{HCH}$ and DDTs were applied mainly as pesticides in cotton fields and they may still have an impact on the environment despite several decades of decomposition. Although current levels of $\mathrm{HCH}$ are below the first standard permissible value at the majority of sampling sites, the residue contents in most samples from historical cotton fields are larger than those in historical non-cotton fields. The $\mathrm{HCH}$ residue is derived from lindane for most non-cotton fields but technical $\mathrm{HCH}$ mixed with lindane for the majority of historical cotton. DDE residues showed significant differences with the residual quantities apparently higher in historical cotton fields than in fields with other cropping histories, and this may be attributed to the widespread application of DDTs in cotton fields.
Fig. 5 Relationship between DDD+DDE and DDTs in surface soils

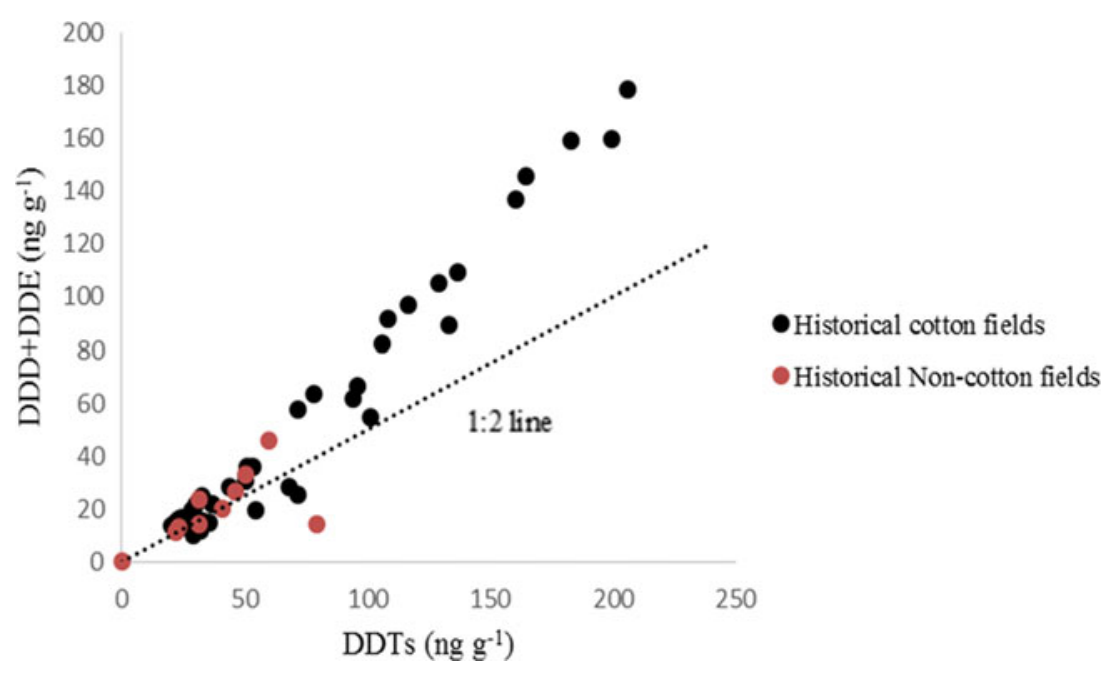


Table 5 Total cancer risks from human exposure via ingestion, dermal absorption, and inhalation

\begin{tabular}{|c|c|c|c|c|}
\hline \multicolumn{2}{|c|}{ Exposure pathways } & \multirow{2}{*}{$\begin{array}{c}\text { Minimum } \\
1.45 \mathrm{E}-08\end{array}$} & \multirow{2}{*}{$\begin{array}{l}\text { Maximum } \\
4.71 \mathrm{E}-08\end{array}$} & \multirow{2}{*}{$\begin{array}{l}\text { Mean } \\
3.30 \mathrm{E}-08\end{array}$} \\
\hline Heptachlor & $\mathrm{CR}_{\text {ingestion }}$ & & & \\
\hline & $\mathrm{CR}_{\text {dermal }}$ & $3.31 \mathrm{E}-08$ & $1.07 \mathrm{E}-07$ & 7.52E-08 \\
\hline & $\mathrm{CR}_{\text {inhal }}$ & $2.73 \mathrm{E}-11$ & $8.86 \mathrm{E}-11$ & $6.20 \mathrm{E}-11$ \\
\hline & $\sum \mathrm{CR}^{\mathrm{a}}$ & 4.77E-08 & $1.55 \mathrm{E}-07$ & $1.08 \mathrm{E}-07$ \\
\hline \multirow[t]{4}{*}{ Chlordane } & $\mathrm{CR}_{\text {ingestion }}$ & $6.09 \mathrm{E}-08$ & 4.24E-06 & $3.64 \mathrm{E}-07$ \\
\hline & $\mathrm{CR}_{\text {dermal }}$ & $3.47 \mathrm{E}-08$ & $2.41 \mathrm{E}-06$ & $2.08 \mathrm{E}-07$ \\
\hline & $\mathrm{CR}_{\text {inhal }}$ & $1.14 \mathrm{E}-10$ & 7.97E-09 & $6.86 \mathrm{E}-10$ \\
\hline & $\sum \mathrm{CR}$ & $9.57 \mathrm{E}-08$ & $6.66 \mathrm{E}-06$ & $5.73 \mathrm{E}-07$ \\
\hline \multirow[t]{4}{*}{$\mathrm{HCH}$} & $\mathrm{CR}_{\text {ingestion }}$ & $9.90 \mathrm{E}-09$ & $1.90 \mathrm{E}-07$ & $6.59 \mathrm{E}-08$ \\
\hline & $\mathrm{CR}_{\text {dermal }}$ & $1.13 \mathrm{E}-08$ & 2.17E-07 & $7.51 \mathrm{E}-08$ \\
\hline & $\mathrm{CR}_{\text {inhal }}$ & $1.86 \mathrm{E}-11$ & $3.58 \mathrm{E}-10$ & $1.24 \mathrm{E}-10$ \\
\hline & $\sum \mathrm{CR}$ & $2.12 \mathrm{E}-08$ & $4.08 \mathrm{E}-07$ & $1.41 \mathrm{E}-07$ \\
\hline \multirow[t]{4}{*}{ DDTs } & $\mathrm{CR}_{\text {ingestion }}$ & 0 & $6.96 \mathrm{E}-07$ & $2.19 \mathrm{E}-07$ \\
\hline & $\mathrm{CR}_{\text {dermal }}$ & 0 & $1.59 \mathrm{E}-06$ & $5.00 \mathrm{E}-07$ \\
\hline & $\mathrm{CR}_{\text {inhal }}$ & 0 & $1.31 \mathrm{E}-09$ & $4.12 \mathrm{E}-10$ \\
\hline & $\sum \mathrm{CR}$ & 0 & $2.28 \mathrm{E}-06$ & $7.20 \mathrm{E}-07$ \\
\hline \multirow[t]{4}{*}{ OCPs } & $\mathrm{CR}_{\text {ingestion }}$ & $2.87 \mathrm{E}-07$ & $4.70 \mathrm{E}-06$ & $6.93 \mathrm{E}-07$ \\
\hline & $\mathrm{CR}_{\text {dermal }}$ & $3.24 \mathrm{E}-07$ & $3.26 \mathrm{E}-06$ & $8.82 \mathrm{E}-07$ \\
\hline & $\mathrm{CR}_{\text {inhal }}$ & $5.40 \mathrm{E}-10$ & 8.84E-09 & $1.30 \mathrm{E}-09$ \\
\hline & $\sum \mathrm{CR}$ & $6.66 \mathrm{E}-07$ & 7.97E-06 & $1.58 \mathrm{E}-06$ \\
\hline
\end{tabular}

${ }^{\mathrm{a}} \sum \mathrm{CR}$, the sum of $\mathrm{CR}_{\text {ingestion }}, \mathrm{CR}_{\text {dermal, }}$ and $\mathrm{CR}_{\text {inhal }}$

\section{Health risk assessment}

The results of human risk assessment for OCPs are shown in Table 5. The ATSDR (Agency for Toxic Substances and Disease Registry) (1995) standard proposes the following qualitative ranking of cancer risk: very low (value $<10^{-6}$ ), low $\left(10^{-6} \leq\right.$ value $\left.<10^{-4}\right)$, moderate $\left(10^{-4} \leq\right.$ value $\left.<10^{-3}\right)$, high $\left(10^{-3} \leq\right.$ value $\left.<10^{-1}\right)$, and very high (value $\left.\geq 10^{-1}\right)$. The cancer risk values of heptachlor and $\mathrm{HCH}$ are all $<10^{-6}$, implying that they represent a very low cancer risk in this region. There are three sampling sites with a CR for chlordane of $>10^{-6}$, illustrating that chlordane may pose a low CR. Although the CR via ingestion and inhalation of DDTs are all $<10^{-6}$, the summation of the three exposure pathways for 14 sampling points are $>10^{-6}$ though the average $\mathrm{CR}$ value is 0.7198 . As shown in Table 5, there are 35 sampling points where the $\sum$ CR value of OCPs is $10^{-6}$, accounting for $67 \%$ of the total number of samples.

\section{Conclusions}

The present study examined the contents and distribution of OCP residues in 52 surface soil samples from the Lvdian region. The OCP concentrations varied from 85 to
$1392 \mathrm{ng} \mathrm{g}^{-1}$ with a mean of $205 \mathrm{ng} \mathrm{g}^{-1}$. HCH, heptachlor, and chlordane showed a $100 \%$ detection rate. The main pesticides, $\mathrm{HCH}$ and DDT, were detected in historical cotton fields and fields with other cropping histories, with mean concentrations of 19.0 , and $21.6 \mathrm{ng} \mathrm{g}^{-1}$ for $\mathrm{HCH}$, and 71.3 , and $38.5 \mathrm{ng} \mathrm{g}^{-1}$ for DDTs. The composition and source identification of $\mathrm{HCH}$ show that the contribution of $\delta-\mathrm{HCH}$ was approximately $53 \%$, the source of $\mathrm{HCH}$ might be attributed mainly to the use of lindane. Moreover, a recent usage of lindane or an atmospheric source for the input is indicated. Though there has been no cotton cultivation for decades, the residue of DDE in historical cotton fields are significantly higher $(P<0.05)$ than those in other fields, and this can be attributable to the degradation of the extensively used DDT for cotton in historically. Also, p,p-DDE was the predominant component of DDTs, resulting from the degradation of DDT under aerobic conditions. The source identification shows that DDTs are derived mainly from historical residues of DDT and a few samples contained newly input DDT. Moreover, the $\Sigma$ $\mathrm{CR}$ average value of OCPs is $1.58 \times 10^{-6}$, indicating that current levels of OCP residues in agricultural soils pose a relatively low cancer risk in Lvdian region.

Acknowledgments We thank the Project for the Infinitus (China) Co., Ltd. (No. HPG/AT/027). We also thank the anonymous reviewers for their valuable comments on an earlier version of the manuscript.

\section{References}

ATSDR (1995) Public health assessment. Johnstown City Landfill, Johnstown, Fulton Country. CERCLIS NO. NYD980506927. In: Dept. of Health and Human Services PHS, Atlanta, New York State Dept. of Health under cooperative agreement with the agency for toxic substances and disease registry, Atlanta

Boonyatumanond R, Jaksakul A, Puncharoen P, Tabucanon MS (2002) Monitoring of organochlorine pesticides residues in green mussels (Perna viridis) from the coastal area of Thailand. Environ Pollut 119:245-252. doi:10.1016/s0269-7491(01)00329-3

Brown MA, Ruzo LO, Casida JE (1986) Photochemical conversion of a dicofol impurity, alpha-chloro-DDT, to DDE. Bull Environ Contam Toxicol 37:791-796

Cai DJ (1996) Pesticide usage in China. Prepared for environment Canada. Downsview

Da CN, Liu GJ, Sun RY, Yuan ZJ, Tang Q, Liu HQ (2014) Sources and risk assessment of organochlorine pesticides in surface soils from the nature reserve of the Yellow River Delta, China. Soil Sci Soc Am J 78:779-786. doi:10.2136/sssaj2013.12.0547

Ge J, Woodward LA, Li QX, Wang J (2013) Composition, distribution and risk assessment of organochlorine pesticides in soils from the Midway Atoll, North Pacific Ocean. Sci Total Environ 452:421426. doi:10.1016/j.scitotenv.2013.03.015

Health Canada (2004) Federal contaminated site risk assessment in Canada, part I: guidance on human health preliminary quantitative risk assessment (PQRA). Environmental Health Assessment Services, Safe Environments Directorate. Health Canada, Ottawa

Kim YS, Eun H, Katase T, Fujiwara H (2007) Vertical distributions of persistent organic pollutants (POPs) caused from organochlorine 
pesticides in a sediment core taken from Ariake Bay, Japan. Chemosphere 67:456-463

Li YF, Cai DJ, Shan ZJ, Zhu ZL (2001) Gridded usage inventories of technical hexachlorocyclohexane and lindane for China with 1/6 degrees latitude by $1 / 4$ degrees longitude resolution. Arch Environ Contam Toxicol 41:261-266

Li J, Zhang G, Qi SH, Li XD, Peng XZ (2006) Concentrations, enantiomeric compositions, and sources of $\mathrm{HCH}$, DDT and chlordane in soils from the Pearl River Delta, South China. Sci Total Environ 372:215-224. doi:10.1016/j.scitotenv.2006.09.023

Liu WX, He W, Qin N, Kong XZ, He QS, Ouyang HL, Yang B, Wang QM, Yang C, Jiang YJ, Wu WJ, Xu FL (2012) Residues, distributions, sources, and ecological risks of OCPs in the water from Lake Chaohu, China. Sci World J. doi:10.1100/2012/897697

MEP (2014) Technical guidelines for risk assessment of contaminated sites. Ministry of Environmental Protection, China (In Chinese)'

NIP (2007) The People's Republic of China National implementation plan for the Stockholm convention on persistent organic pollutants

Qiu XH, Zhu T, Jing L, Pan HS, Li QL, Miao GF, Gong JC (2004) Organochlorine pesticides in the air around the Taihu Lake, China. Environ Sci Technol 38:1368-1374. doi:10.1021/es035052d

Qiu XH, Zhu T, Yao B, Hu JX, Hu SW (2005) Contribution of dicofol to the current DDT pollution in China. Environ Sci Technol 39:43854390. doi:10.1021/es050342a

Qu CK, Qi SH, Yang D, Huang HF, Zhang JQ, Chen W, Yohannes HK, Sandy EH, Yang JH, Xing XL (2015) Risk assessment and influence factors of organochlorine pesticides (OCPs) in agricultural soils of the hill region: a case study from Ningde, Southeast China. J Geochem Explor 149:43-51. doi:10.1016/j.gexplo.2014.11.002

Shi Y, Meng F, Guo F, Lu Y, Wang T, Zhang H (2005) Residues of organic chlorinated pesticides in agricultural soils of Beijing, China. Arch Environ Contam Toxicol 49:37-44. doi:10.1007/s00244-004-0087-z

Strandberg B, Bavel BV, Bergqvist PA, Broman D, Ishaq R, Naf C, Pettersen H, Rappe C (1998) Occurrence, sedimentation, and spatial variations of organochlorine contaminants in settling particulate matter and sediments in the northern part of the Baltic Sea. Environ Sci Technol 32:1754-1759

Sui H, Wu P, Song J, Huang YJ, Li QB, Yu HB, Lu MC (2013) Establishment of sample pretreament method for the determination of low levels of DDT in soil. J Instrum Anal 32(11):1369-1373 (in Chinese)

UNEP (United Nations Environment Program) (2003) Regionally based assessment of persistent toxic substances. Global report. UNEP Chemicals, Geneva

USEPA (1989) Risk assessment guidance for superfund (RAGS), volume I: human health evaluation manual (Part F, supplemental guidance for inhalation risk assessment). Human health evaluation manual. EPA/540/1-89/002, vol. I. Office of Solid Waste and Emergency Response. U.S. Environmental Protection Agency. Washington, DC. Available at: http://www.epa.gov/oswer/riskassessment/ragsf/

USEPA (1997) Exposure factors handbook-general factors. EPA/600/P95/002Fa, vol. I. Office of Research and Development. National Center for Environmental Assessment. U.S. Environmental Protection Agency. Washington, DC. Available at: http:/www.epa. gov/ncea/pdfs/efh/front.pdf (Accessed 15 April 2014)

USEPA (2001) Supplemental guidance for developing soil screening levels for superfund sites. OSWER 9355.4-24. Office of Solid Waste and Emergency Response. U.S. Environmental Protection Agency. Available at: http://www.epa.gov/superfund/health/ conmedia/soil/index.htm

USEPA (2009) Risk assessment guidance for superfund. Human health evaluation manual $(\mathrm{F}$, supplemental guidance for inhalation risk assessment). EPA/540/R/070/002, Vol. I. Environmental Protection Agency, Washington, DC. Available at: http:/www.epa.gov/iris/ subst/0278.htm\#carc

Wang F, Bian YR, Jiang X, Gao HJ, Yu GF, Deng JC (2006) Residual characteristics of organochlorine pesticides in Lou soils with different fertilization modes. Pedosphere 16:161-168. doi:10.1016/ s1002-0160(06)60039-8

Wang F, Jiang X, Bian YR, Yao FX, Gao HJ, Yu GF, Munch JC, Schroll R (2007) Organochlorine pesticides in soils under different land usage in the Taihu Lake region, China. J Environ Sci (China) 19: 584-590. doi:10.1016/s1001-0742(07)60097-7

Wei DB, Kameya T, Urano K (2007) Environmental management of pesticidal POPs in China: past, present and future. Environ Int 33: 894-902. doi:10.1016/j.envint.2007.04.006

Wong MH, Leung AOW, Chan JKY, Choi MPK (2006) A review on the usage of POP pesticides in China, with emphasis on DDT loadings in human milk (vol 60, pg 740, 2005). Chemosphere 64:696. doi:10. 1016/j.chemosphere.2005.11.004

Wu CW, Zhang AP, Liu WP (2013) Risks from sediments contaminated with organochlorine pesticides in Hangzhou, China. Chemosphere 90:2341-2346. doi:10.1016/j.chemosphere.2012.10.023

Wu CF, Luo YM, Gui T, Huang YJ (2014) Concentrations and potential health hazards of organochlorine pesticides in (shallow) groundwater of Taihu Lake region, China. Sci Total Environ 470:1047-1055. doi:10.1016/j.scitotenv.2013.10.056

Xue ND, Wang HB, Xu XB (2005) Progress in study on endocrine disrupting pesticides (EDPs) in aquatic environment. Chin Sci Bull 50:2257-2266. doi:10.1360/982005-348

Xue ND, Zhang DR, Xu XB (2006) Organochlorinated pesticide multiresidues in surface sediments from Beijing Guanting reservoir. Water Res 40:183-194

Yang RQ, Jiang GB, Zhou QF, Yuan CG, Shi JB (2005) Occurrence and distribution of organochlorine pesticides (HCH and DDT) in sediments collected from East China Sea. Environ Int 31:799-804. doi: 10.1016/j.envint.2005.05.027

Yang XL, Wang SS, Bian YR, Chen F, Yu GF, Gu CG, Jiang X (2008) Dicofol application resulted in high DDTs residue in cotton fields from northern Jiangsu province, China. J Hazard Mater 150:92-98. doi:10.1016/j.jhazmat.2007.04.076

Yang HY, Xue B, Yu P, Zhou SS, Liu WP (2010) Residues and enantiomeric profiling of organochlorine pesticides in sediments from Yueqing Bay and Sanmen Bay, East China Sea. Chemosphere 80: 652-659. doi:10.1016/j.chemosphere.2010.04.052

Yang D, Qi SH, Zhang JQ, Tan LZ, Zhang JP, Zhang Y, Xu F, Xing XL, Hu Y, Chen W, Yang JH, Xu MH (2012) Residues of organochlorine pesticides (OCPs) in agricultural soils of Zhangzhou City, China. Pedosphere 22:178-189

Zhang HB, Luo YM, Zhao QG, Wong MH, Zhang GL (2006) Residues of organochlorine pesticides in Hong Kong soils. Chemosphere 63: 633-641. doi:10.1016/j.chemosphere.2005.08.006

Zhang HB, Luo YM, Li QB (2009) Burden and depth distribution of organochlorine pesticides in the soil profiles of Yangtze River Delta Region, China: implication for sources and vertical transportation. Geoderma 153:69-75. doi:10.1016/j.geoderma.2009.07.016

Zhao ZH, Zhang L, Wu JL, Fan CX (2009) Distribution and bioaccumulation of organochlorine pesticides in surface sediments and benthic organisms from Taihu Lake, China. Chemosphere 77:1191-1198. doi:10.1016/j.chemosphere.2009.09.022

Zhao ZH, Zeng HA, Wu JL, Zhang L (2013) Organochlorine pesticide (OCP) residues in mountain soils from Tajikistan. Environ Sci Processes Impacts 15:608-616. doi:10.1039/c2em30849e 